\title{
AKUISISI DAN BUDAYA KNOWLEDGE SHARING
}

\author{
Nuril Kusumawardhani Soeprapto Putri
}

Fakultas Ilmu Komputer, Jurusan Sistem Informasi, Binus University

Jl. KH. Syahdan No. 9, Palmerah, Jakarta Barat 11480.

nuril@binus.ac.id

\begin{abstract}
Large companies which are experiencing barriers in innovation often take a radical step to acquire knowledge, namely acquisition. Though innovation is not the only reason, acquisition will result in the company wishes to achieve competitive advantage affected by the creation of ideas, creativity and innovation. The three points can be achieved more easily when the knowledge sharing within the organization / company runs well. However, the acquisition maybe impacts as a counter-attack for the knowledge sharing culture both in the acquisitor and and company which obtains the acquisition. Therefore, a key to succeed the acquisition is a sharing culture among individuals within a company that runs well or even better. Individuals from the acquisitor and those of the company that obtains the acquisition can adapt to each other and have confidence in order not to hinder them to share knowledge. This study discusses in detail the potential impacts of an acquisition upon a knowledge sharing culture in a company.
\end{abstract}

Keywords: knowledge sharing, acquisition, company innovation.

\begin{abstract}
ABSTRAK
Perusahaan besar yang mengalami hambatan dalam proses inovasi seringkali mengambil langkah radikal untuk mendapatkan pengetahuan, yaitu dengan akuisisi. Walaupun inovasi bukanlah satu-satunya alasan, secara keseluruhan akuisisi akan berujung pada keinginan perusahaan untuk meraih keunggulan kompetitif yang dipengaruhi penciptaan ide, kreatifitas dan inovasi. Ketiga hal tersebut dapat diraih lebih mudah apabila iklim berbagi (sharing) pengetahuan dalam organisasi/perusahaan berjalan dengan baik. Namun, dampak yang ditimbulkan oleh akuisisi dapat menjadi serangan balik bagi budaya knowledge sharing dalam perusahaan yang mengakuisisi maupun yang mengalami akuisisisi. Sehingga salah satu kunci keberhasilan dari proses akuisisi adalah budaya berbagi antar individu dalam suatu perusahaan yang berjalan dengan baik atau bahkan lebih baik. Individu dari perusahaan yang mengakuisisi dengan individu dari perusahaan yang diakuisisi dapat saling beradaptasi dan memiliki kepercayaan sehingga tidak menghambat mereka untuk berbagi pengetahuan. Kajian ini membahas secara rinci mengenai dampak yang dapat ditimbulkan oleh aktifitas akuisisi terhadap budaya knowledge sharing di suatu perusahaan.
\end{abstract}

Kata kunci: berbagi pengetahuan, akuisisi, inovasi perusahaan. 


\section{PENDAHULUAN}

Iklim ekonomi di Indonesia disemarakkan dengan berbagai aktifitas merger dan akuisisi perusahaan lokal oleh perusahaan asing terutama di sektor perbankan. Pada November 2002, Commerce Asset-Holding Berhad (CAHB), yang kini dikenal sebagai CIMB Group Holdings Berhad, mengakuisisi sebagian besar saham Bank Niaga dari tangan Indonesia Bank Restructuring Agency (IBRA). Jejak ini diikuti oleh Malayan Bank atau yang lebih dikenal dengan Maybank dengan mengakuisisi Bank International Indonesia (BII) walaupun sempat melalui langkah yang tersendat. Selain sektor perbankan, akuisisi ini juga terjadi di sektor lainnya, diantaranya adalah dua perusahaan rokok kretek terkenal di Indonesia, Sampoerna dan Bentoel telah diambil alih oleh pihak asing. Sampoerna yang yang diakuisisi oleh Philip Morris di tahun 2005 dan Bentoel yang baru saja diakuisisi oleh British American Tobacco (BAT). Aktifitas merger dan akuisisi tidak hanya berhenti sampai disini, kesuksesan pendahulunya memicu perusahaan lokal lainnya untuk mengikuti jejak perusahaan-perusahaan ternama di negeri ini. Fenomena ini menimbulkan polemik di masyarakat yang mengkhawatirkan meningkatnya angka pengangguran akibat dari akuisisi tersebut. Pabrik rokok padat karya kemungkinan akan digantikan oleh peralatan canggih yang akan berdampak pada pengurangan karyawan. Disisi lain, jika melihat dari corporate culture yang mengakuisisi dengan yang diakuisisi akan tampak perbedaan yang amat mencolok. Awal mula berdirinya perusahaan-perusahaan tersebut ditangani oleh pimpinan yang berbudaya lokal mengikuti budaya Indonesia, tergantikan oleh budaya asing yang memungkinkan terjadinya culture shock. Hal ini, secara langsung akan berdampak pada proses transfer pengetahuan (Knowledge Sharing/Transfer) antar karyawan di dalam perusahaan tersebut.

Untuk menghindari resiko pemutusan hubungan kerja (PHK), memungkinkan bagi karyawan perusahaan yang mengalami akuisisisi atau mengalami merger untuk berusaha meningkatkan kinerjanya dengan semakin membatasi diri dalam berbagi ilmu yang dimilikinya. Kondisi yang lainnya adalah memungkinkan adanya tuntutan yang semakin berat di dalam budaya yang berbeda, sehingga membuat karyawan semakin bergantung satu sama lain. Budaya asing yang dinamis bisa menyadarkan para karyawan untuk tidak menyimpan ilmu yang dimilikinya dan berbagi dengan yang lain, atau budaya yang baru itu justru membawa iklim individualistis antar karyawan sesuai dengan budaya perusahaan yang ada. Akan tetapi, bisa saja perubahan budaya tersebut tidak membawa dampak apapun bagi karyawan perusahaan dikarenakan kekentalan budaya perusahaan sebelumnya yang mendarah daging pada diri mereka. Tulisan ini akan membahas permasalahan di atas sekaligus cara untuk mengatasi dampak negatif dari proses akuisisi oleh perusahan terhadap budaya knowledge sharing/transfer.

\section{METODE}

Dalam kajian ini, penulis menggunakan studi literatur sebagai bahan penyusunan. Sumbersumber kepustakaan yang digunakan diperoleh dari buku, jurnal, hasil-hasil penelitian dan sumbersumber lainnya yang sesuai (internet, dll). Selain itu, observasi juga dilakukan terhadap fakta-fakta empiris yang ada.

\section{HASIL DAN PEMBAHASAN}

\section{Akuisisi dan Dampaknya terhadap Kinerja Karyawan}

Menurut Business Dictionary online, akuisisi dapat didefinisikan sebagai pengambilalihan saham perusahaan sebesar atau lebih dari 51\% saham perusahaan tersebut. Selain kekuatan merek 
dagang, asset, serta proses inovasi yang menjadi alas an, akuisisi juga dapat membantu perusahaan yang berkembang dalam suatu industri tertentu untuk tumbuh dengan cepat tanpa membuat badan usaha yang lain.

Permasalahan yang sering dihadapi dalam proses akuisisi adalah alasan pemanfaatan modal intelektual (merek dagang, aset serta inovasi) terkadang tidak mempertimbangkan faktor-faktor yang dapat mempengaruhi kinerja karyawan. Konsep bisnis, produk dan prospek pasar memang merupakan faktor kunci, namun karakter dari karyawan yang tercermin dari budaya perusahaan merupakan faktor yang tidak dapat dikesampingkan dan menjadi pemicu keberhasilan dari proses akuisisi. Turunnya motivasi kerja dikarenakan oleh situasi yang penuh ketidakpastian, perubahan peran, jabatan dan tanggung jawab, kurangnya tantangan yang dikarenakan perubahan management style, serta perubahan budaya perusahaan menjadi beberapa faktor lain di dalam perusahaan yang mengalami akuisisisi maupun yang mengakuisisi.

Nikondrau \& Papalexandris (2008) memaparkan beberapa dampak negatif dari proses akuisisi terhadap karyawan, diantaranya adalah rasa pengkhianatan, perjuangan, kemarahan, kekhawatiran, stres dan ketidakpastian adalah beberapa istilah untuk mendeskripsikan perasaan para karyawan setelah proses akuisisi. Dampak negative lainnya adalah meningkatnya perilaku negatif dari para karyawan, seperti ketidakhadiran, waktu kerja yang tidak produktif, sabotase dan meningkatnya kesalahan kerja.

Salah satu contoh proses pengakuisisian perusahaan, dialami oleh karyawan Banco ABN yang bergabung dengan AMRO Bank sehingga membentuk ABN-AMRO Bank (Tanure \& GonzalesDuarte, 2007). Para karyawan Banco pada awalnya memiliki perasaan "ditinggalkan” oleh pendiri Banco, Dr Aloysio Faria. Para Top eksekutif, terutama CEO dari ABN-AMRO mengantisipasi masalah ini dengan menekankan pada karyawan eks Banco ABN bahwa mereka bukanlah pencudang. Fabio Barbosa bahkan menekankan "Kami membeli Bank ini karena kesuksesannya". Hal ini dilakukan untuk menumbuhkan rasa percaya diri di mata para karyawan eks Banco ABN.

\section{Akuisisi dan Corporate Culture}

Budaya merupakan pola asumsi secara tacit yang telah dipelajari oleh suatu kelompok dalam pemecahan permasalahan adaptasi eksternal dan integrasi internal, yang telah berjalan dengan baik dan dianggap sah, sehingga dapat diajarkan kepada para anggota baru cara yang benar untuk melihat, berpikir dan memecahkan permasalahan (Schein, 2009). Budaya merupakan properti dalam sebuah kelompok. Jika suatu kelompok dinilai telah memiliki pengalaman yang cukup, di situlah budaya mulai terbentuk. Budaya tumbuh dalam setiap level dari departemen, kelompok fungsional dan dari unit organisasi lain yang memiliki kesamaan pekerjaan dan pengalaman (Schein, 2009). Budaya perusahaan atau corporate culture memiliki dampak yang cukup besar terhadap kinerja suatu perusahaan. Menurut Krefting\&Frost (1985) pada tulisan karya Lai\&Lee (2007), budaya organisasi dapat mendukung keunggulan kompetitif (competitive advantage) dengan cara memfasilitasi interaksi antar individu atau memberikan ruang lingkup untuk proses arus informasi.

Berkaitan dengan konteks akusisi, suatu organisasi atau perusahaan yang mengalami akuisisisi secara otomatis akan menjadi subbudaya dari budaya yang lebih besar pada perusahaan yang mengakuisisi. Namun pada joint venture, di mana perusahaan yang bergabung akan mendirikan suatu organisasi baru, tidak ada istilah subbudaya. Hal ini karena dua budaya dari dua organisasi/perusahaan itu akan tergabung dan mereka akan memulainya dari awal.

Di saat seorang pimpinan dari perusahaan yang mengakuisisi berhadapan dengan karyawan dari perusahaan yang mengalami akuisisisi, ada permasalahan budaya yang akan dihadapi. Schein (2009) mengungkapkan empat macam tindakan terhadap corporate culture, yang dapat dipilih oleh seorang pimpinan suatu perusahaan yang mengakuisisi perusahaan lain. Tindakan pertama terhadap 
budaya perusahaan adalah menghancurkan budaya perusahaan yang mengalami akuisisisi dan mengimplementasikan budaya perusahaan yang mengakuisisi. Resiko dari tindakan ini adalah hilangnya pengetahuan, keahlian dan "know-how" diiringi dengan turunnya performa perusahaan tersebut. Tindakan yang kedua adalah mengadakan perlawanan terhadap budaya yang ada, dengan memaksakan keyakinan, nilai-nilai dan asumsi-asumsi pada setiap karyawan/anggota dari perusahaan yang mengalami akuisisisi. Resiko dari tindakan ini adalah proses adaptasi yang hanya terjadi pada permukaannya saja. Mereka menunggu hingga masa jabatan pimpinan berakhir, dan akan kembali kepada budaya yang dianut sebelumnya. Kemudian yang ketiga adalah menyerah pada budaya yang telah dianut oleh perusahaan yang mengalami akuisisi, dengan cara meninggalkan keyakinan, nilai dan asumsi yang dianut oleh pimpinan yang mengakuisisi. Resiko dari tindakan ini adalah semua elemen dari budaya lama akan terus dianut, padahal beberapa elemen itu mungkin sudah usang dan tidak berfungsi lagi, sehingga harus dilakukan perusahan.Terakhir dengan melakukan evolusi budaya secara bertahap. Hal ini dilakukan dengan membiarkan karyawan perusahaan yang mengalami akuisisisi untuk beradaptasi terhadap lingkungan baru, kemudian secara sedikit demi sedikit memaksakan aturan-aturan baru, perilaku, nilai-nilai keyakinan dan asumsi yang dimiliki oleh perusahaan yang mengakuisisi.

Bagi banyak perusahaan, alternatif terakhir (melakukan evolusi budaya secara bertahap) merupakan cara yang paling disukai. Sedangkan untuk sebuah organisasi atau perusahaan yang telah lama berdiri, evolusi budaya merupakan satu-satunya alternatif yang dapat dilakukan yang berujung pada kesuksesan suatu proses akusisi.

\section{Knowledge Sharing dan Corporate Culture}

Gurteen (1999) mengemukakan bahwa knowledge sharing atau knowledge transfer dapat diimplementasikan dengan cara mendorong individu untuk bekerja bersama secara efektif, berkolaborasi, dan saling berbagi dengan tujuan untuk meningkatkan produktifitas pengetahuan organisasi. Sejalan dengan pemikirin Gumus (2007), para individu akan lebih banyak melakukan penyebaran knowledge dan keahlian yang dimiliki jika berada di dalam lingkup kelompoknya sendiri, dibandingan diluar kelompoknya (out-groups). Hal ini disebabkan oleh rasa saling percaya antar individu dalam suatu kelompok lebih kuat dibandingkan ketika dia berada di luar kelompoknya. Trust (Kepercayaan) merupakan faktor utama yang mendukung terjadinya knowledge transfer/sharing. Tanpa rasa saling percaya maka akan mustahil bagi para karyawan untuk berbagi, berkolaborasi dan berkomunikasi dengan sesamanya (Yang, 2004). Selain rasa saling percaya pada diri para individu yang berada dalam suatu kelompok, biasanya mereka memiliki ikatan emosional untuk secara sukarela memberikan pengetahuan yang dimilikinya (Weiss di Chua, 2003).

Berdasarkan studi dari Khamseh \& Jolly (2008) knowledge transfer sangatlah diperlukan dalam suatu perusahaan, karena memberikan akses kepada pengetahuan yang berada di luar jangkauan mereka. Perusahaan akan mencoba untuk belajar, berbagi pengetahuan dan mengakuisisinya melalui interaksi dari dalam dan diluar lingkungan perusahaan tersebut. Atmosfir positif yang dibawa melalui knowledge sharing akan menstimulasi organisasi di seluruh dunia untuk mengimplementasikannya secara sah (Davenport \& Prusak, 1998). Sehingga, perusahaan yang dikategorikan "berhasil” adalah perusahaan yang memiliki kemampuan untuk menangkap pengetahuan yang diakuisisi oleh salah satu bagian dari perusahaan dan disebarkan pada bagian yang lain (Chua, 2003).

Dalam prakteknya, proses pendistribusian pengetahuan dalam suatu perusahaan atau organisasi dapat mengalami hambatan. Petersen (2001) di Rumyantseva et.al (2002) mengemukakan lima hambatan utama dalam proses pendistribusian pengetahuan yaitu, budaya, perilaku kepemimpinan, kurangnya tanggung jawab dalam repositori pengetahuan, kurangnya tinjauan dan pengukuran terhadap modal intelektual, dan tidak terstruktur dengan baik (Gambar 1). 


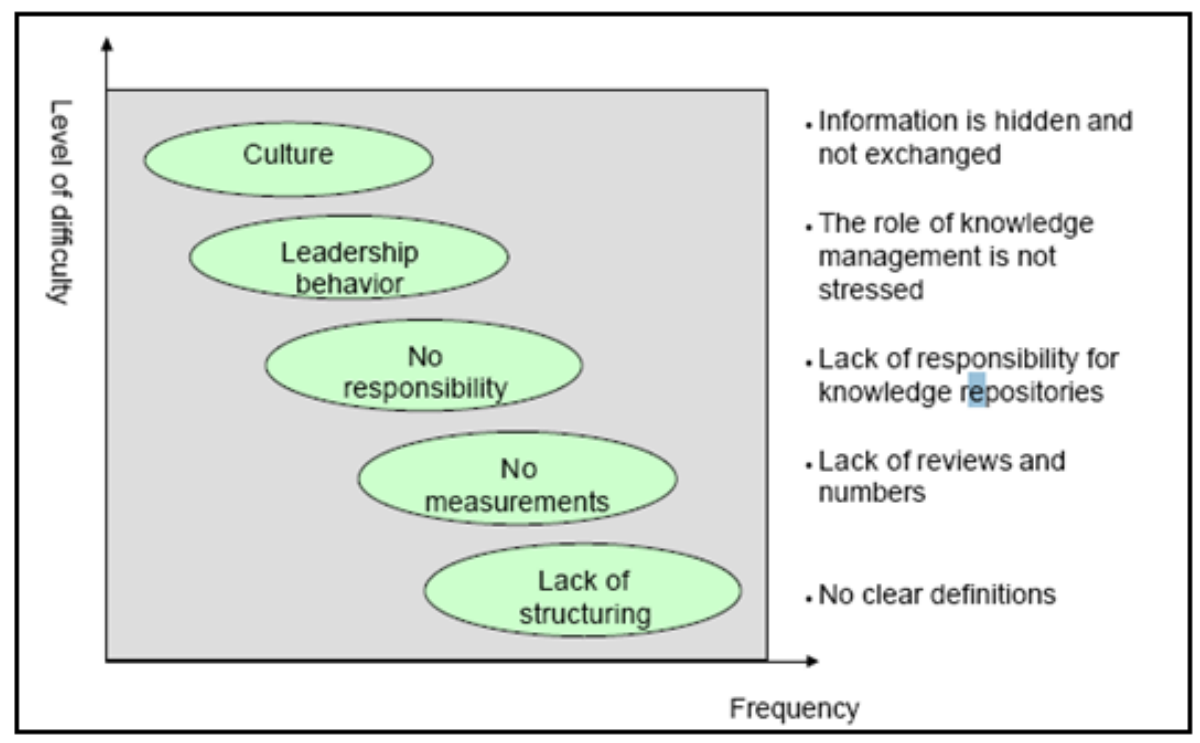

Gambar 1. Hambatan pendistribusian pengetahuan dalam perusahaan.

Dari Gambar 1 dapat dilihat bahwa budaya menempati urutan yang utama dan memiliki tingkat kesulitan yang paling tinggi. Knowledge sharing yang didukung oleh budaya perusahaan dapat mengarah pada pencapaian yang lebih efektif karena budaya merupakan modal yang bersifat intangible 'nyata, berwujud' yang mendukung perilaku berbagi (sharing) antar karyawan dalam suatu organisasi/perusahaan. Ladd \& Ward (2002) mengidentifikasi hubungan antara empat tipe dasar dari budaya organisasi (organization culture) dengan knowledge transfer. Keempat tipe budaya organisasi tersebut adalah: (1) opennes to change/innovation, (2) task-oriented, (3) bureaucratic dan (4) competition/confrontation (Gambar 2). Opennes to change/innovation merupakan budaya suatu organisasi yang memiliki karakterisitik keterbukaan pada perubahan dan inovasi akan memaksa para individunya untuk saling berinteraksi demi meningkatkan pengetahuan individu (individual knowledge). Task-Oriented adalah budaya perusahaan yang mengacu pada orientasi hasil akan meningkatkan konvergensi dari shared goals oleh organisasi dan para anggotanya. Konvergensi ini akan didapatkan dengan transfer pengetahuan antar individu dalam suatu perusahaan. Bureaucratic terjadi dimana suatu organisasi yang menghambat komunikasi interpersonal akan memperlemah hubungan antar chanel yang ada. Selain itu, suatu budaya yang mendorong rasa ketergantungan terhadap satu individu dengan individu lainnya akan menghambat proses pembentukan pengetahuan individu. Dari kedua hal tersebut dapat ditarik hipotesis bahwa sebuah organisasi dengan budaya birokrasi akan memberikan dampak negatif pada proses transfer pengetahuan (knowledge transfer). Poin yang terakhir adalah Competition atau Confrontation. Budaya kompetisi dan konfrontasi akan menghambat hubungan interpersonal dalam suatu organisasi. Hal lainnya, suatu budaya yang memaksa individunya untuk meraih power/kekuasaan maka akan berdampak pada individual goals dan mengesampingkan organizational goals. Sehingga, dengan alasan tersebut, dapat ditarik kesimpulan bahwa suatu organisasi dengan budaya kompetisi/konfrontasi akan membawa dampak yang negatif terhadap knowledge transfer.

\section{Akuisisi dan Budaya Knowledge Sharing/Knowledge Transfer}

Perubahan budaya di dalam suatu organisasi atau perusahaan bukanlah suatu hal yang dapat dimaklumi oleh setiap individu yang terkait. Dalam konteks akuisisi, perubahan kebiasaan, aturan, nilai yang selama kurun waktu tertentu telah dianut dalam keseharian menjadi suatu tantangan berat baik bagi perusahaan yang mengakuisisi maupun yang mengalami akuisisisi. Maka dapat dikatakan bahwa proses akuisisi akan berjalan lebih lancar jika dilakukan pada dua perusahaan yang memiliki 
kemiripan dari segi budaya perusahaan. Adaptasi yang dilakukan oleh kedua belah pihak terutama bagi karyawan perusahaan yang mengalami akuisisisi akan berjalan lebih cepat. Seperti yang terlihat pada Gambar 3 mengenai proses integrasi akusisi, jika atmosfer suatu organisasi mendukung proses transfer pengetahuan, inovasi yang berdampak pada keunggulan kompetitif dapat diraih.

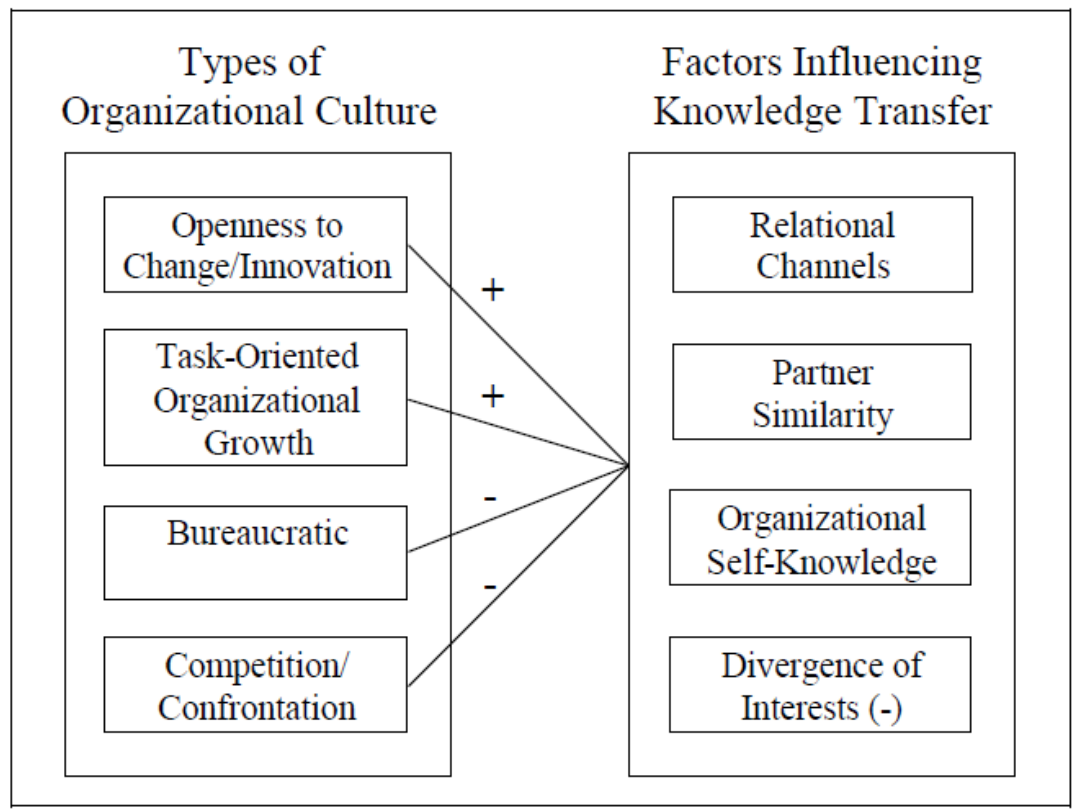

Gambar 2.Tipe budaya organisasi dengan faktor yang mempengaruhi knowledge transfer.

Timbulnya rasa kekhawatiran, stress dan ketidapastian yang disebabkan oleh ketakutan akan kehilangan jabatan bagi karyawan perusahaan yang mengalami akuisisisi, secara langsung akan menghambat proses knowledge sharing dalam organisasi/perusahaan. Individu di dalamnya akan semakin sulit untuk mempercayai rekan sekerjanya untuk berbagi pengetahuan dikarenakan mereka hanya memikirkan nasib dan kinerjanya sendiri. Akusisi perusahaan juga bisa membawa dampak yang positif terhadap budaya knowledge sharing/knowledge transfer. Hal ini bergantung pada management style dan leadership dari kepemimpinan yang baru (perusahaan yang mengakuisisi). Jika iklim budaya sharing pada perusahaan yang mengalami akuisisisi lebih rendah dibandingkan dengan perusahaan yang mengakuisisi, maka lambat laun para karyawan dari perusahaan yang mengalami akuisisisi akan terbawa untuk meningkatkan performa knowledge sharing antar individu. Management style yang terbuka pada perubahaan, ide dan inovasi dari pihak pimpinan perusahaan yang mengakuisisi juga dapat meningkatkan perasaan nyaman bagi para karyawan yang mengalami akuisisisi dan memacu mereka untuk meningkatkan jiwa kompetisi diiringi dengan sikap saling berbagi, tanpa memiliki rasa khawatir terhadap hilangnya jabatan yang dimiliki.

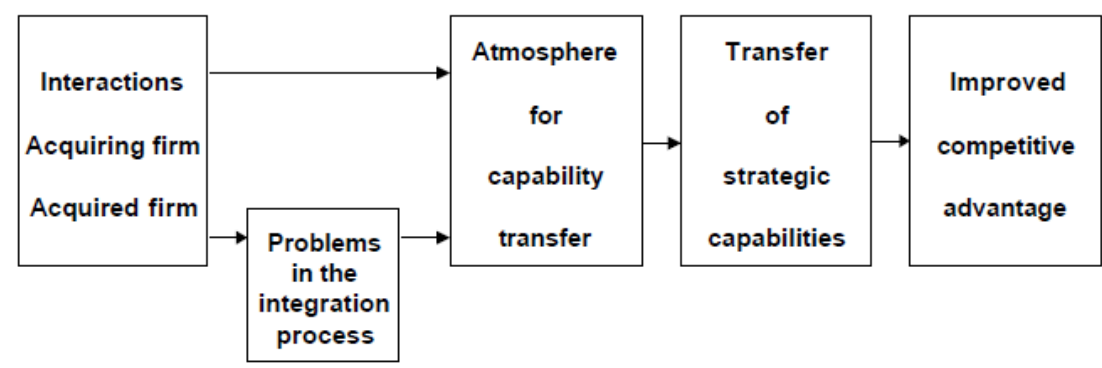

Gambar 3. Proses integrasi akuisisi. (Sumber: Rumyantseva et al., 2002) 
Memfokuskan mereka pada organizational goal sehingga mereka tidak terpaku pada individual goal, menjadi salah satu tindakan yang dapat membawa keberhasilan dalam suatu akuisisi. Hal ini dilakukan untuk menghindari karyawan yang mengutamakan individual power yang membuat mereka sulit untuk berbagi pengetahuan terhadap yang lain. Walaupun iklim kompetisi sangatlah penting, jangan sampai mereka terpaku pada target individu yang membawa perilaku karyawan ke arah individualitas. Perlunya keseimbangan antara kompetisi dan proses berbagi antar karyawan tersebut.

Membuat para karyawan menjadi merasa nyaman tanpa harus "dilabelkan” mana yang karyawan mengalami akuisisisi dan mana yang berasal dari perusahaan yang mengakuisisi, akan mempercepat tingkat komunikasi yang lebih baik antar mereka. Sering diadakannya pertemuan antar karyawan yang berasal dari dua belah perusahaan juga dapat digunakan sebagai sarana ice breaker, sehingga mereka bisa lebih mengenal satu sama lain dalam suasana yang informal. Komunikasi, kunjungan dan pertemuan-pertemuan merupakan hal-hal yang dapat memfasilitasi terjadinya knowledge sharing atau transfer dalam situasi akusisi (Rumyantseva et.al., 2002).

Bagi perusahaan yang diakuisisi oleh perusahaan yang berasal dari negara yang berbeda atau seperti yang telah terjadi pada iklim akuisisi di Indonesia, di mana makin banyak perusahaan asing yang mengakuisisi perusahaan lokal, tantangan yang dihadapi oleh budaya knowledge sharing atau transfer akan semakin besar. Perusahaan lokal yang memiliki budaya cerminan dari budaya Indonesia seperti, sikap hormat yang tinggi terhadap para karyawan senior atau atasan, rasa enggan untuk mengemukakan pendapat atau ide terhadap atasan dikarenakan ketakutan untuk melakukan kesalahan merupakan dua contoh budaya yang dapat menghambat terjadinya pendistribusian pengetahuan. Sebaliknya, iklim perusahaan asing yang terbuka terhadap kritik, saran dan ide akan membawa pengaruh yang lebih baik bagi karyawan perusahaan yang mengalami akuisisisi untuk meningkatkan rasa percaya dirinya dan juga meningkatkan rasa saling berbagi. Namun, perubahan itu tidak mungkin dilakukan secara cepat. Budaya yang sudah mendarah daging di dalam diri para karyawan, membutuhkan waktu yang cukup lama untuk merubahnya. Karena itu, tindakan evolusi budaya secara bertahap merupakan tindakan yang paling tepat dilakukan bagi perusahaan yang memiliki iklim budaya yang tradisional dan sudah terpatri cukup lama. Pihak perusahaan yang mengakuisisi tidak mungkin dapat melakukan pemaksaan secara ekstrim untuk mengubah budaya perusahaan yang mengalami akuisisisi. Pihak manajemen dan pihak karyawan yang mengakuisisi haruslah cukup sabar untuk melakukan pendekatan terhadap para karyawan yang mengalami akuisisisi.

\section{Kasus Merger Compaq dengan HP}

Pada tahun 2003, terjadi merger antara dua perusahaan besar, yaitu Compaq dengan Hewlett Packard (HP). Merger ini terjadi di Cina, dimana pihak HP China sudah terlebih dahulu mengadopsi ilmu KM pada tahun 2001. Para karyawan perusahaan Compaq merasa posisinya terancam dengan adanya merger tersebut. Mereka menolak untuk berbagi pengetahuan dengan para karyawan HP China, dikarenakan oleh kekhawatiran akan kehilangan posisi atau jabatan mereka sekarang. Iklim knowledge sharing yang sudah terbangun sebelumnya di kalangan karyawan HP China makin terhapus dan mengakibatkan CRO mereka - Gao Jianhua - mengundurkan diri. Gao merasakan kekecewaan yang mendalam setelah bersusah payah membangun budaya knowledge sharing yang cukup kuat di kalangan karyawan HP China sebelumnya.

Budaya masyarakat Cina, menjadi alasan utama mengapa knowledge sharing/transfer tidak berjalan dengan baik. Filosofi "a good mastery of a single skill ensures a lifetime employment" dan, "An outstanding apprentice will leave the master starving (without a job)", begitu mendarah daging dalam diri mereka. Mereka begitu takut kehilangan ilmu yang mereka miliki sehingga mereka juga takut untuk membaginya dengan orang lain. Seperti halnya, para guru kungfu yang tidak mengajarkan secara keseluruhan ilmu yang dimilikinya kepada muridnya. Setidaknya, satu ilmu unggulan harus tersimpan hanya untuk diri sendiri. 
Pada awal penerapan KM di HP China, Gao memfokuskan pada pembentukan lingkungan kerja yang menunjang knowledge sharing/transfer antar karyawannya. Teknologi dikembangkan setelah iklim sharing itu terbentuk dengan baik. Pengembangan dokumentasi pengetahuan, standarisasi perilaku kerja, pembentukan asosiasi Book-Reading, pendirian institusi pembelajaran baik secara formal maupun informal, serta sistem reward bagi karyawan yang mau berbagi pengetahuan menjadi agenda awal Gao. Cara ini dianggap sukses oleh HP China, hingga terjadinya merger tersebut (Lin et al., 2006). Akibat dari merger yang dilakukan oleh Compaq dengan HP, langkah yang sudah ditempuh Gao harus dimulai dari awal kembali. Pembentukan iklim sharing yang baik antara kedua perusahaan tersebut haruslah dijembatani dengan baik. Para karyawan Compaq harus diberikan jaminan atas pekerjaan yang mereka miliki saat ini, sehingga rasa khawatir tidak akan timbul. Diperlukan kerjasama yang baik dengan para karyawan HP China agar tidak mengintimidasi para karyawan Compaq, sehingga kedua pihak dapat saling percaya satu sama lain. Di saat trust sudah didapatkan, proses berbagi pengetahuan akan dapat berjalan.

\section{PENUTUP}

Aktifitas akuisisi yang semakin menjamur di kalangan para pengusaha membawa dampak bervariasi baik terhadap pihak perusahaan yang mengakuisisi dan yang mengalami akuisisisi serta karyawan dari kedua belah pihak. Di sisi lain, implementasi knowledge management mengalami perkembangan yang signifikan. Keberhasilan dari implementasi knowledge management tidak hanya bergantung pada faktor teknologi, tapi juga dari proses dan faktor sumber daya manusia. Dibutuhkan budaya sharing yang cukup baik di dalam suatu organisasi atau perusahaan agar proses penciptaan pengetahuan (knowledge creation) menjadi lebih mudah.

Salah satu kunci keberhasilan dari suatu aktifitas akuisisi dinilai dari tercapainya inovasi yang lebih baik. Maka dari itu, dibutuhkan budaya sharing yang baik antar karyawan, baik dari karyawan perusahaan yang mengakuisisi maupun karyawan perusahaan yang mengalami akuisisi. Komunikasi menjadi faktor utama keberhasilan proses pendistribusian pengetahuan dalam aktifitas akuisisi. Komunikasi yang baik dalam setiap level perusahaan baik bagi pihak karyawan yang sudah lama maupun karyawan yang baru bergabung (mengalami akuisisisi) akan menciptakan sinergi yang baik bagi iklim pendistribusian pengetahuan. Pihak manajemen diharapkan tidak membeda-bedakan antara karyawan dari perusahaan yang mengalami akuisisisi dengan perusahaan yang mengakuisisi. Selain itu, dibutuhkan jangka waktu yang cukup untuk proses adaptasi bagi karyawan yang diakuisisi. Penelitian lebih lanjut sangatlah dibutuhkan dalam kajian ini, terutama pada perusahaan yang sedang melakukan akuisisi. Hal tersebut dilakukan agar dampak yang dihadapi akan lebih terperinci dan cara penanganannya juga akan lebih tepat.

\section{DAFTAR PUSTAKA}

Acquisition. (n.d.). Dalam Business Dictionary online. Diakses dari http://www.businessdictionary.com/definition/acquisition.html.

Chua, Alton (2003). Knowledge Sharing: A Game People Play. Aslib Proceeding, 55 (3), 117-129.

Davenport, Thomas H., dan Prusak, Laurance. (1998). Working Knowledge: How Organizations Manage What They Know. Boston: Harvard Business School Press. 
Gurteen, David. (1999). Creating a Knowledge Sharing Culture. Diakses dari http://www.providersedge.com/docs/km_articles/Creating_a_K-Sharing_Culture__Gurteen.pdf.

Khamseh, H. M. dan Jolly, D. R. (2008). Knowledge Transfer in Alliances: Determinant Factors. Journal of Knowledge Management, 12 (1), 37-50.

Ladd, A. dan Ward, M. A. (2002). An Investigation of Environmental Factors Influencing Knolwedge Transfer. Journal of Knowledge Management Practice, 4.

Lai, Ming-Fong dan Lee, G. (2007). Risk Avoiding Cultures Toward Achievement of Knowledge Sharing. Business Process Management Journal, 13 (4).

Lin, Lu, Kwok dan Leung. (2006). Challenges to KM at Hewlett Packard China. Knowledge Management Review. Diakses dari http://findarticles.com/p/articles/mi_qa5362/is_200603/ai_n21390989/pg_2/.

Rumyantseva, M., Gurgul, G., dan Enkel, E. (2002). Knowledge Integration after Mergers \& Acquisition. Discussion $\quad 48.4$ Daper, Diakses dari http://strategylab.ifb.unisg.ch/org/ifb/ifbweb.nsf/SysWebRessources/beitrag48/\$FILE/DB48.p df.

Schein, Edgar H. (2009). The Corporate Culture Survival Guide. New York: Jossey-Bass. 